1 UNAIDS, UN Population Fund, UN Development Fund for Women Women and HIV/AIDS: confromting the crisis. New York: UN Population Fund, 2004. www.unfpa.org/hiv/women/report/index.htm (accessed 1 Sep 2005)

2 Annan K. In Africa, AIDS has a woman's face. New York Times 2002 Dec 29.

UNAIDS. Fourth report on the global AIDS epidemic. Geneva: UNAIDS 2004.

Cohen S. Beyond slogans: Lessons from Uganda's experience with ABC and HIV/AIDS. Reprod Health Matters 2004;12:132-5.

5 Gupta GR. How men's power over women fuels the HIV epidemic. BMJ 2002;324:183-4.

6 United Nations General Assembly Special Session on HIV/AIDS. Declaration of Commitment on HIV/AIDS, 2001. www.unaids.org/html/pub/ publications/irc-pub03/AIDSDeclaration_en_pdf/ publications/irc-pub03/AIDSDeclaration_en_pdf/

AIDSDeclaration_en_pdf_l.jpg (accessed 1 Sep 2005).
Rojanapithayakorn W, Hanenberg R. The $100 \%$ condom program in Thailand. AIDS 1996;10:1-7

8 Winkelstein W, Wiley JA, Padian NS, Samuel M, Shiboski S, Ascher MS, et al. The San Francisco men's health study: continued decline in HIV seroconversion rates among homosexual/bisexual men. Am J Public Health $1988 ; 78: 1472-4$

9 Sumartojo E, Doll L, Holtgrave D, Gayle HD, Merson MH. Enriching the mix: incorporating structural factors into HIV prevention. AIDS 2000;14(suppl 1):S1-2

10 Holden S. Mainstreaming HIV/AIDS in development and humanitarian programmes. Oxford: Oxfam GB, 2004

11 Human Rights Watch. Double standards:women's property rights violations in Kenya. New York: Human Rights Watch, 2003.

12 Daley-Harris S. State of the microcredit summit campaign report 2004 Washington, DC: Microcredit Summit Campaign, 2004. www.microcreditsummit.org/pubs/reports/socr/2004/SOCR04.pdf (accessed 1 Sep 2005)

13 Sachs J. The end of poverty: How we can make it happen in our lifetime. London: Penguin, 2005.

14 Cheston S, Kuhn L. Empowering women through microfinance. In: Harris SD, ed. Pathways out of poverty: innovations in microfinance for the poorest families. Bloomfield: CT: Kumarian Press, 2002:167-228.

15 UNAIDS. Gender and HIV/AIDS: taking stock of research and programmes. Geneva: UNAIDS, 1999.

16 Schuler S, Hashemi S, Riley A. The influence of women's changing roles and status in Bangladesh's fertility transition: evidence from a study of credit programmes and contraceptive use. World Development 1997:25:563-75.

17 Schuler SR, Hashemi SM, Riley AP, Akhter S. Credit programs, patriarchy, and men's violence against women in rural Bangladesh. Soc Sc Med 1996;43:1729-42

18 Goetz AM, Gupta SR. Who takes the credit? Power and control over loan use in rural credit programs in Bangladesh. World Development 1996;24:45-63.

19 Population Council. Power in sexual relationships: an opening dialogue among reproductive health professionals. New York: Population Council, 2001.

20 Mayoux L. Women's empowerment and micro-finance:programmes, approaches evidence, and ways forward. Milton Keynes: Open University, 1998. (Development policy and practice working paper 41.)

$21 \mathrm{Ahmed} \mathrm{SM.} \mathrm{Intimate} \mathrm{partner} \mathrm{violence} \mathrm{against} \mathrm{women:} \mathrm{experiences} \mathrm{from}$ a woman-focused development programme in Matlab, Bangladesh. $J$ Health Popul Nutr 2005;23:95-101.

22 Pronyk PM, Kim JC, Hargreaves JR, Makhubele MB, Morison LA, Watts $\mathrm{CH}$, et al. Microfinance and HIV prevention: perspectives and emerging lessons from rural South Africa. Small Enterprise Development (in press).

23 Microcredit Summit Campaign. African microenterprise AIDS initiative. http://www.microcreditsummit.org/press/Africanmicro.htm (accessed 2 Sep 2005).

24 Microcredit Summit Campaign. What about the other Africa? http:// www.microcreditsummit.org/press/other.htm (accessed 2 Sep 2005).

25 Kirubi M, Ngugi EN, Kamau P, Nyanbola L, Ronald A. The impact of social, economic and sexual empowerment:commercial sex workers [abstract 447D].X international conference on AIDS, Yokohama, 1994.

26 Communication Initiative. Programme experiences: Rusape girls empowerment village, Zimbabwe. www.comminit.com/experiences/pds22004 experiences-515.html (accessed 2 Sep 2005).

27 Population Council. Tostan breakthrough in Senegal: ending female genital cutting. Dakar: Population Council, 1999.

28 Hargreaves J, Pronyk P, Kim J, Makhubele M, Watts C, Morison L, et al The intervention with microfinance for AIDS and gender equity study (IMAGE): www.wits.ac.za/radar/IMAGE studyhtm

29 BBC News. Brown calls for 5.5 billion pound AIDS fund. BBC News World Edition 2005 Jan 13. http://news.bbc.co.uk/2/hi/uk_news/politics/ $4170531 \mathrm{stm}$ (accessed 2 Sep 2005).

30 Sanders D, Labonte R, Baum F, Chopra M. Making research matter: a civil society perspective on health research. Bull World Health Org 2004;82:757-63.

\title{
Patients' readiness to start highly active antiretroviral treatment for HIV
}

\author{
Hirut T Gebrekristos, Koleka P Mlisana, Quarraisha Abdool Karim
}

Assessing whether patients are ready to start antiretroviral treatment may improve HIV prevention and treatment outcomes

Centre for AIDS Programme of Research in South Africa (CAPRISA) Nelson R Mandela, School of Medicin Durban, South Africa

Hirut T

Gebrekristos research fellow Koleka P Mlisana project director

Quarraisha Abdool

Karim

associate professor

Correspondence to: H T Gebrekristos hgebrekr@jhsph.edu

BMJ 2005;331:772-5
Initiatives to increase access to antiretroviral treatment in resource constrained settings are growing, but the scale and magnitude of the HIV epidemic in these settings raises a number of operational and ethical challenges. Most people infected with HIV are unaware of their status, and people who are aware of their status fear stigmatisation and discrimination. Key themes about access to treatment include who gets treatment, when is the best time to start treatment, and how to ensure therapeutic success.

Numerous guidelines for treatment have been developed nationally and internationally. One concern is how initiation of antiretroviral treatment should relate to patients' readiness and commitment. Although patients' readiness is emphasised as a requirement for starting treatment in several guidelines,${ }^{1-4}$ the guidelines are neither clear nor in consensus about what constitutes readiness and how this readiness should be assessed. Given this ambiguity, readiness may be used to ration resources, particularly in resource poor settings, in which access to antiretrovirals is currently gaining support. The potential of using readiness to improve HIV prevention and care outcomes, however, mandates that we closely examine the use of readiness for starting highly active antiretroviral treatment (HAART).

Studies about assessing patients' readiness for starting HAART or the impact of this on therapeutic success are few. One small study found that lack of readiness resulted in interrupted treatment and risky sexual behaviour; therefore, readiness for treatment may help care givers to make decisions about when to start treatment with antiretrovirals for each patient. ${ }^{5}$ The potential importance of treatment readiness for therapeutic success is why a more structured and systematic approach to evaluating readiness is needed. In addition, a systematic evaluation of the use of treatment readiness becomes particularly important in settings where "readiness" may be misused to ration resources. Rigorously collected data will be critical in shaping appropriate interventions that go beyond anecdotal notions that readiness is important in determining when to start HAART. 
Clinical indicators have been central to debates on when to initiate HAART, where CD4 cell count is a key determining factor. ${ }^{6-9}$ By incorporating a compulsory drug readiness programme into decisions on starting treatment, the South African government's HAART rollout plan expands this debate. ${ }^{10}$ The South African plan is fairly detailed and specific in requiring education on HIV/AIDS, positive living, opportunistic infections, care and treatment for HIV/AIDS, HAART side effects, and the importance of treatment adherence. Although early in its implementation, the South African HAART rollout plan not only expands the debate on when to initiate therapy, but may also provide an opportunity to understand and evaluate the benefit of treatment readiness for decisions on HAART initiation.

What are possible ways of understanding and ascertaining patients' readiness for starting HAART? Intuitively, we would expect there to be a range of levels for readiness depending, among other things, on disease state, knowledge and understanding of antiretrovirals, levels of stigma and discrimination, sex, existing support structures, and motivation. Given the complex set of factors that are likely to influence readiness, what minimum level of readiness should distinguish between decisions to start or delay treatment? Using the South African HAART rollout plan as a point of departure, we present a framework for how readiness may be understood and suggest a possible method that may help in measuring readiness.

\section{What constitutes adequate readiness to start HAART?}

One way of considering and distinguishing between different levels of treatment readiness is to think in terms of variations of health literacy, including three

\section{Box 1: Readiness to start drug treatment \\ Before starting \\ Basic \\ - Basic knowledge of HIV transmission and prevention \\ - Understanding of antiretroviral treatment, the side effects of treatment, and belief in treatment efficacy \\ - Ability to comprehend, cope, and comply with prescribed actions, such as treatment adherence and safer sexual practices \\ - Willingness to create support systems to cope with HIV status and facilitate treatment, such as disclosing status to family, friends, and partners}

\section{After starting}

Functional

- Advanced knowledge and skills to cope and manage HIV status and treatment that is grounded on experiences

- Ability to recognise and seek care for opportunistic infections

Critical

- Considerable level of knowledge, personal autonomy, skills, and confidence to manage the consequences of HIV status and treatment

- Capacity to take action that encourages health and discourages the determinants of ill health, such as substance abuse, unsafe sexual practice, and adherence

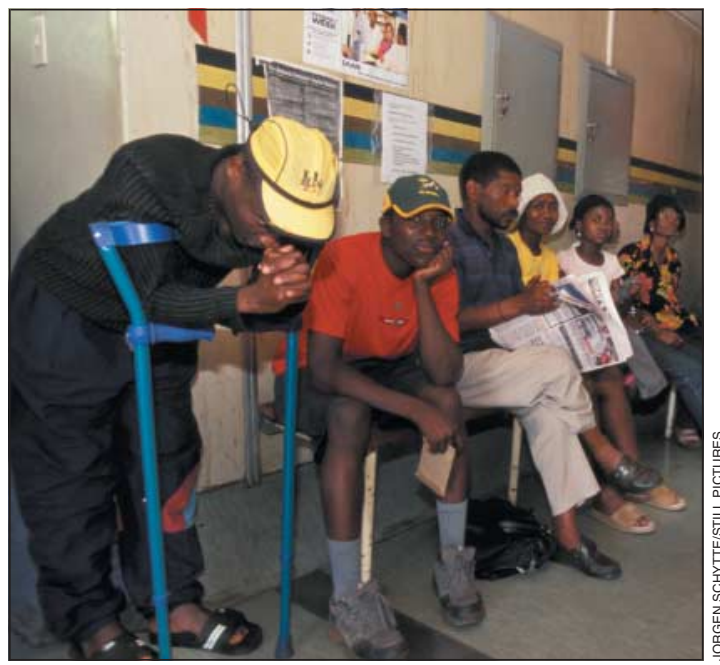

Patients waiting at the doctors clinic at the Leratong Hospital in Krugersdorp

broad categories-basic, functional, and critical literacy. ${ }^{11}{ }^{12}$ Within this context, readiness can range from knowledge of basic information about antiretroviral treatment to a more comprehensive approach that empowers patients not only to understand the fundamentals involved in participating in treatment but also includes the social skills and capacity to effectively access other pertinent health services and maintain good health. Using these three categories as a foundation, box 1 gives a framework for understanding HAART treatment readiness.

In box 1, we have distinguished between the minimum readiness before starting treatment (basic) and the levels of readiness that may result from having treatment (functional and critical readiness). Readiness is also likely to be influenced by personal and social factors. For example, someone who has the support of family or friends and the personal drive to participate in treatment, but who does not have the basic information to start treatment, will have a different set of needs before becoming ready than someone who may have the information but lacks personal will and social support to participate in treatment. In this context, preparing the person with the information deficit is less challenging. In other words, what constitutes readiness for starting treatment should take all of these elements into account. Although we have given a somewhat polarised example, there can be different levels of knowledge, personal initiative, social support, etc. The readiness required to start treatment is also likely to be different from the readiness required to maintain successful participation in antiretroviral treatment programmes in an individual's lifetime. In addition, interactions with patients and care givers may also affect thinking and action about readiness-and, more importantly, the interface between patients and care givers is likely to influence whether patients maintain long term readiness for HAART after starting. The process of building patients' readiness, therefore, must be supportive and encouraging.

After participation in a drug-readiness programme, patients should fulfil at least the criteria listed under basic readiness. The functional and critical levels of readiness may precede starting treatment or may be attained at various points in the course of treatment 
and will vary among people, but every effort should be made to move people forward through active collaboration with community organisations, non-state run programmes, and other sources of support.

Box 2 shows the factors that constitute basic treatment readiness. Based on factors that have been used to assess readiness for behavioural changes, readiness for HIV treatment may include an understanding of the need for treatment, drive to live, and knowledge and capacity to maintain and build on commitment. ${ }^{13-15}$ Personal responsibilities over these categories may differ by sex and age group, but what constitutes readiness should remain consistent. Children and young adolescents or adults with mental disabilities may not completely understand the consequences of their illness or the expected commitment required for treatment initiation and maintenance and will therefore require a care giver to support them during treatment. Care providers of HIV infected children should, therefore, participate in the drug readiness programme. Adolescents may or may not require a care giver or parent to participate for them to enrol in treatment, although it would be more beneficial.

\section{Can readiness to start HAART be measured?}

To date, a few small studies have measured readiness to start treatment using MEMS (medication event monitoring systems). ${ }^{16}$ This strategy has use for measuring drug adherence but is inadequate for assessing the broader concept of readiness. Experience garnered in assessing readiness in substance abuse treatment programmes, ${ }^{17-20}$ despite considerable differences between the needs of the people in such programmes and patients starting HIV treatment, gives some important principles for assessing readiness for HIV treatment. Both groups, for example, face challenges with incorporating life changes and coping with their diagnosis that require high levels of long term commitment for success. Substance misuse

\section{Box 2: Basic readiness}

Need

The person initiating treatment must understand that treatment can extend health and productive life. The participants must trust that treatment will be helpful. This is one of the factors that could be bolstered by experience on treatment.

Drive to live

This desire may be supported or discouraged by other aspects in life (family, children, partners, and friends). A component of the drive to live should include an assessment of shame, stigma, and how perceived or experienced discrimination is a force in the person's life. Understanding a person's drive to live may be guided by their expressions of fear for death. Within this context, assessing the presence and magnitude of anger, depression, and other emotionally distressing elements could be useful.

\section{Capacity}

Knowledge about HIV prevention and transmission and basic knowledge about the process of treatment and how treatment works, including side effects, is essential. A basic understanding that treatment works by "reducing the virus" in the body and the need to maintain viral suppression. Patients should understand the importance of adherence to treatment and safe sexual practice. Patients need confidence in their ability to meet expectations of commitment to treatment, including the coping strategies to maintain emotional stability.

\section{Summary points}

No clarity or consensus exists on what constitutes patients' readiness for HIV treatment and how readiness should be assessed

The more established and readily measurable criteria currently used in decisions to start highly active antiretroviral treatment (HAART) need to be expanded

Understanding the use of treatment readiness is particularly critical in settings where its role in initiating therapy may be misused to ration resources

programmes have used psychometric assessment scores to assess readiness. Based on basic readiness for treatment with antiretrovirals, as outlined in box 2, it is feasible to develop and test the reliability of psychometric measures. Importantly, operational research that monitors and measures the relationship between readiness and treatment outcomes is critical.

As the World Health Organization and UNAIDS's " 3 by 5 " initiative takes shape (to give three million people with HIV/AIDS in low and middle income countries antiretroviral treatment by the end of 2005), and as nations with limited resources increase access to HIV treatment, understanding and measuring readiness may become useful for HIV prevention and treatment outcomes. However, countries should be cautious about using readiness to ration access to treatment. Importantly, the assessment of readiness needs to be viewed as a process to advance all patients to a level of readiness that will support starting treatment and ensure equitable access to therapy. Developing sound criteria without restricting access to treatment is a challenging task that is integrally linked to the definition and measurement of readiness for treatment. The South African plan gives a valuable point of departure beyond the existing anecdotal notions that readiness is important in determining when to start HAART. We have presented a potential way forward in understanding how to construct, measure, and unpack the potential benefits of readiness for HIV prevention and treatment outcomes, but rigorous tools are required to assess various constructs of readiness.

We thank Motshedisi Sebitloane, department of medicine at the University of KwaZulu-Natal, and Jerome Singh, Centre for AIDS Programme of Research in South Africa.

Contributors and sources: The idea for the manuscript grew out of collaborative discussions on patient and provider challenges facing the South African HAART rollout plan. HTG searched the literature and drafted and revised the manuscript. KPM and QAK contributed to drafting and revising the manuscript. OAK gave additional guidance and direction for the paper. HTG is guarantor.

Funding: National Institute of Allergy and Infectious Diseases, National Institutes of Health, US Department of Health and Human Services (1U19AI51794), and Research Supplement for Under-represented Minorities to the Brown/Tufts/Lifespan, Center for AIDS Research, Brown University, Providence, Rhode Island (P30 AI42853-05S1).

Competing interests: None declared. 
1 British HIV Association (BHIVA) guidelines for the treatment of HIV-infected adults with antiretroviral therapy. London: BHIVA Writing Committee on behalf of the BHIVA Executive Committee, 2003. www.bhiva.org/ guidelines/2003/hiv/index.html (accessed 26 Apr 2004).

2 Department of Health and Human Services. Guidelines for the use of antiretroviral agents in HIV-1-infected adults and adolescents. Rockville: DHHS, 2003. www.aidsinfonih.gov/guidelines/adult/AA 111003.pdf (accessed 26 Apr 2004).

3 Ministry of Health, Republic of Uganda. Antiretroviral treatment policy. Republic of Uganda, Ministry of Health, 2003.

4 British HIV Association. New French guidelines for antiretroviral treatment. HIV Med 2000;1:133-6.

5 Enriquez M, Lackey NR, O'Connor MC, Mckinsey DS. Successful adherence after multiple HIV treatment failures. J Adv Nurs 2004;45:438-46.

6 Harrington D, Carpenter CC. Hit HIV-1 hard, but only when necessary. Lancet 2000;355:2147-52

7 Lane HC, Neaton JD. When to start therapy for HIV infection: A swinging pendulum in search of data. Ann Intern Med 2003;138:680-1.

8 Skolnik PR. HIV therapy: what do we know, and when do we know it? N Engl J Med 2003;349:2351-2.

9 Yeni PG, Hammer SM, Carpenter CC, Cooper DA, Fischl MA, Gatell JM, et al. Antiretroviral treatment for adult HIV infection in 2002: updated recommendations of the International AIDS Society-USA Panel [Corrected in JAMA 2003;11:32]. JAMA 2002;288:222-35.

10 Department of Health, South Africa. Operational plan for comprehensive HIV and AIDS care and treatment for South Africa. Pretoria: DH, 2003. www.gov.za/issues/hiv/careplan19nov03.htm (accessed 1 Sep 2005).

11 Nutbeam D. Health literacy as a public health goal: a challenge for contemporary health education and communication strategies into the 21st century. Health Promot Int 2000;15:259-67.

12 Nutbeam D, Kickbusch I. Advancing health literacy: a global challenge for the 21st century. Health Promot Int 2000;15:183-4.

13 Blumenthal RN, Gogineni A, Longshore D, Steinl M. Factors associated with readiness to change drug use among needle exchange users. Drug Alcohol Depend 2001;62:225-30.

14 Audrain J, Caminero A, Robertson A, Boyd R, Orlens C, Lerman C. Gender and ethnic differences in readiness to change smoking behaviour. Women Health 1997;3:139-50.

15 Rohren C, Corghan I, Hurt R, Offord K, Marusic A, McClain F. Predicting smoking cessation outcome in a medical centre from stage of readiness: contemplation versus action. Prev Med 1994;23:335-44.

16 Wagner G, Iguchi M, Schneider S, Scott J, Anderson D. Placebo practice trials: a tool to assess and improve adherence readiness. HIV Clin Trials 2002;3:475-83.

17 De Leon G, Melnick G, Kressel D, Jainchill N. Circumstances, motivation, readiness and suitability (the CMRS scales): predicting retention in therapeutic community treatment. Am J Drug Alcohol Abuse 1994;20:495-515.

18 Miller WR, Tonigan JS. Assessing drinkers' motivation for change: the stage of change readiness and treatment eagerness scale (SOCRATES). Psychol Addict Behav 1996;10:81-9.

19 NeffJA, Zule W. Development of a measure of treatment readiness for out of treatment drug users: psychometric properties and construct validity. Subst Use Misuse 2000;35:585-99.

20 Prochaska JO, DiClemente CC, Norcross JC. In search of how people change: applications for addictive behaviours. Am Psychol 1992;47: 1102-14.

\section{Achieving food security in vulnerable populations}

\section{Deborah Cohen}

Communities who rely on raising livestock are most vulnerable to hunger when drought or other disaster strikes. How can aid organisations provide effective help?

Hunger and malnutrition cause tremendous human suffering and cost developing countries billions of dollars in lost productivity and national income. The number of hungry people in the world rose to $852 \mathrm{mil}-$ lion between 2000 and 2002, up by 18 million from the mid-1990s, and the total number of hungry people in sub-Saharan Africa is 203 million, a third of the population. ${ }^{1}$ The human and economic costs of hunger will increase if the trend is not reversed. I visited northwest Kenya to see how organisations work to try to improve food security in pastoralist communities.

\section{Food security}

The 2004 annual report from the Food and Agriculture Organization says that little is done globally to fight hunger, although the resources needed to combat it are small compared with the benefits. ${ }^{1}$ Every dollar invested in reducing hunger can give from five to over 20 times as much in benefits. The report recommends giving priority to actions to improve food security.

But food security is a complex issue. A country or region is food secure when: "All people, at all times, have both physical and economic access to sufficient food to meet their dietary needs for a healthy and productive life." ${ }^{2}$ Food security depends principally on three variables: availability of food, access to food and a nutritious diet, and proper use of food to ensure maximal nutrition and hygiene. ${ }^{3}$ In turn, each of these variables is influenced by several factors, the most important of which is poverty; others include the national and international economic environment,

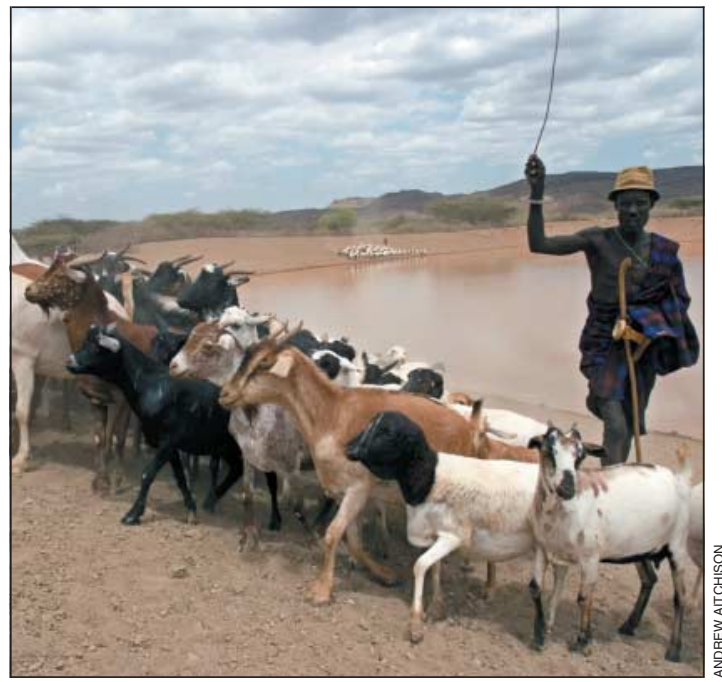

$B M J$, London WC1H 9JR Deborah Cohen assistant editor dcohen@bmj.com BMJ 2005;331:775-7

Kaeris reservoir was built by the community to store drinking water for animals

population growth, infrastructure, the climate, the level of investment and donor commitment, access to appropriate training and job skills, asset base, conflict and access to pasture, and the quality of diet, health, and sanitation.

Because of the number of influencing factors, a multilateral approach involving both the international community and national governments is needed. Some factors, such as economic conditions and infrastructure, are the responsibility of national governments and the international community as a 